\title{
Examination of UNDP Goal Orientation of CSR Activities towards Sustainable Development by Corporates in Pharmacy Sector
}

\author{
Damodar R. Kulkarni, Ashok G. Ranade
}

\begin{abstract}
In recent decade, the two words viz. "Corporate Governance" and "Corporate Social Responsibility (CSR)" have been seeking increasing attention stake holders. The ultimate result of them is assumed that they should turn into sustainable development of the country.

There are two dimensions to these concepts. The one dimension is of statutory compliance and another is non statutory initiatives. Thus, every company is spending on activity in some form which falls under the task of discharging the social responsibility.

However, it is interesting to look at these activities from the goals of the sustainable development. The indicators of sustainable development are the results of these activities. These goals are also reflected from the nature of activities undertaken by a corporate.

United Nations Development Program (UNDP) has given the list of 17 goals which are in recommendatory nature and it is expected that all countries should work towards the achievement of these goals.

The authors intend to study these goals and analyses these activities from the direction point of view towards the goal. There are in all 17 goals/results are considered for the purpose of analysis. The data is taken from the most authentic source i.e. annual reports of the companies from Pharmacy sector for the year 2018-19. The activities are classified based on their nature.

Further, they are examined in the light of these goals/objectives in which there are very high propensity to result into these goals. Comparison is made on the parameters that whether conducting the activities in a particular sector will lead to progressing towards achievement of these goals.

With reference to above said analysis and the literature regarding Corporate Responsibility and Corporate Governance have given their suggestions. These suggestions shall be useful in creation of objectivity for the Corporate towards the Sustainable Growth and discharge their responsibilities more meaningfully.
\end{abstract}

Keywords: Sustainable Development, CSR Initiatives, UNDP, Domain Sector, Direction Orientation towards Sustainable Development Goals (SDGs).

\section{INTRODUCTION}

In recent decade, the two words viz. "Corporate Governance" and "Corporate Social Responsibility" have been seeking increasing attention stake holders. The ultimate result of them is assumed that they should turn into sustainable development of the country.
There are two dimensions to these concepts. The one dimension is of statutory compliance and another is non-statutory initiatives. Thus, every company is spending on activity in some form which falls under the task of discharging social responsibility.

However, it is interesting to look at these activities from goals of the sustainable development. The indicators of sustainable development are the results of these activities.

Although they are indicators, the goals are different and being those goals are very-very wide to come into reality and subject to variations according to the time, place, region etc. Thus, one can look at the directions of the activities and their outcome whether conform to the goals which are formulated by UNDP.

After an achievement of different short-term goals, progressively results into the growth. Such accumulated results of the growth in different areas, like Health care, Education, Sanitation, Rural Development etc. gets leveraging effect and synergic effects leads to long term benefit like Stability of Income, rise in standard of living of those who are at the bottom of the pyramid, Financial and social inclusions of masses in different areas of the lives of the people of the country.

Thus, the paper attempts to discuss about the concept of sustainability, CSR and Sustainability goals which would like peeping into different dimensions of the same.

\section{CONCEPT AND DEFINITIONS OF SUSTAINABILITY AND CSR}

\subsection{Dimensions of Sustainability}

Look at these dimensions followed below which covers concept and definition and other related issues.

There is an increased concern over issues like climate and environment change, poverty, increased disparity between societies, increased materialistic approach towards life and imbalance between three independent systems like

a) Natural Environment,

b) Social and political system and

c) Global Economy.

There are three distinct, but independent sub systems are governing today's business. These are

Revised Manuscript Received on February 06, 2020.

Correspondence Author

CMA.Dr.Damodar Kulkarni*, Finance professional. Fellow member of

"Institute of Cost Accountants of India

E-mail ID: drkulkarni0511@gmail.com

Dr.Ashok Ranade ,Retired Professor,India 


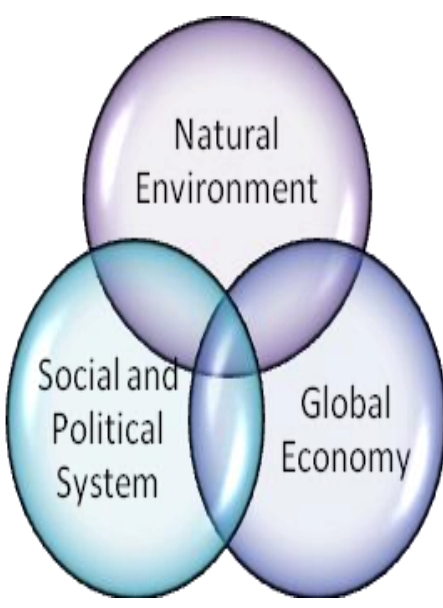

Figure 1 Three Interdependent System of Survival

Thus, the imbalance between the different systems and their subsystems has been creating risks to the country itself and to rest of the countries. The imbalance is increasing, United Nations Organization have taken the cognizance of these risks and appealed the different countries to take responsible steps, UNO has its own agenda and chalked out different plans and programs.

Thus, all the countries should try to reduce the imbalance and mitigate the risks. CSR activities should be in harmony with these dimensions.

The responsibility of showing concern about giving the future generation more beneficial living should be the prime focus area of Sustainability and Development.

2.2 Definitions of Sustainable Development,

Sustainable Manufacturing and Sustainable

Consumption

Sustainable Development

"Sustainable development as "Development that meets the needs of the present without compromising the ability of the future generation to meet their own needs."

As per The Brundtland Commission report released in 1987 by United Nations World Commission on Environment and Development. (Hill P,2012). There are two aspects related to Manufacturing and consumption.

\section{Sustainable manufacturing}

"Sustainable Manufacturing refers to developing and practicing technologies to transform materials into finished products with reduction in each of; energy consumption, emission of greenhouse gases, generation of waste, use of non-renewable or toxic materials."

\section{Sustainable Consumption}

"Sustainable Consumption and Production (SCP) is about the use of services and related products which respond to basic needs and bring a better quality of life while minimizing the use of natural resources, improving resource efficiency, increasing use of renewable energy resources, reducing release of toxic materials and emissions of waste and pollutants over the life cycle of the service or product so as not to jeopardize the needs of the future generations." (https://sustainabledevelopment.un.org/index.php?menu=20 4) 1
Both the definitions reflect that the processes should be so that they would not disturb the ecological balance and shall result into giving "BETTER QUALITY OF LIFE" In nutshell, the concept of sustainability and its different issues rotate around offering Better Quality of Life like Material Quality, Aesthetic Quality, Ethical Quality, Spiritual Quality and such other components of the same, to the present generations and sustaining them for the future generation. Sustainability is such a vast concept and having many dimensions it cannot be caught in capsule form and therefore it becomes illusive for a common man. However, some fundamental features can describe it in indicative way.

\subsection{Key Features of Sustainable Development}

- The fundamental belief behind the philosophy of Sustainable Development is, we must consider factors beyond conspicuous consumption and material possessions. There are other important factors like conservation of natural resources and optimum use of available resources.

- In achieving sustainable development, we must try to strike the balance between ENVIRONMENT AND DEVELOPMENT.

- Sustainable Development is an approach that will permit continuing improvements in the quality of life with a lower intensity of resource use, thereby leaving behind for future generations an undiminished or even enhanced stock of natural resources and other assets

- Sustainable development means making sure that the things we do, the goods we buy and the lifestyle that we have today will not harm the environment for us, for the people in other places and for future generations

- Looking at the consumption and waste

- Thinking about careful use of Earth's resources

- Realizing that we are responsible for our actions and what we do can have a huge effect on other places and people Thus, it seems from the above features that ultimately as an eternal outcome, it can be equated to creation of Peace, Prosperity, Happiness, and Avoidance of violence against nature. Sustainability can be seen from the point of view of growth in development of Indices of Happiness propounded by the king of Bhutan. King of Bhutan has devised an alternative indicator for GDP as a tool to measure progress or development. The levels of Gross National Happiness (GNH) for an individual and for Bhutan as a country are determined through measures in nine domains shown in below figure. 


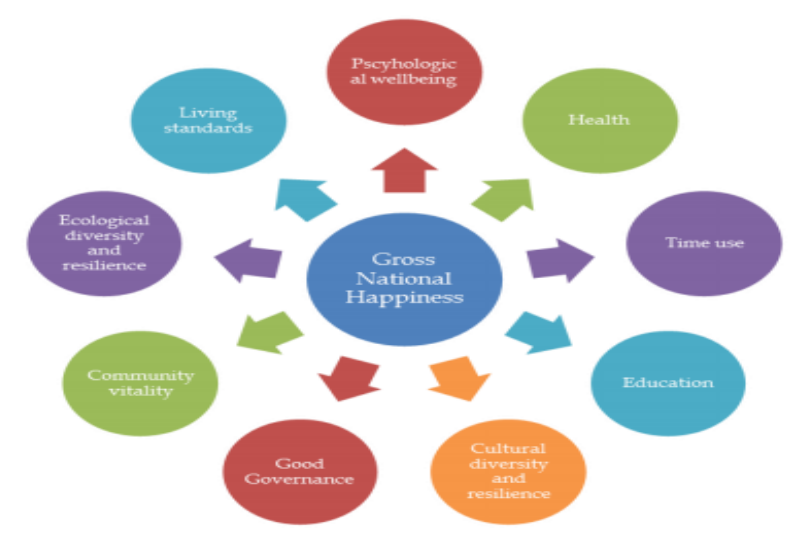

Figure 2The Nine Domains of $\mathbf{G N H}^{2}$

Source :Bergink Jasper, 2016

The societies have undergone the changes. Initially, it had been oriented towards the ownership of stock of assets like land, cattle, animals and such other natural resources.

Then there was a shift after industrial revolution towards the ownership of Manufactured Goods and their processes to maximize the wealth.

With the beginning of $19^{\text {th }}$ century, the entire orientation of human being shifted towards the consumption.

Hereafter, a man started desiring maximum goods and services for his consumption and fanatically derives the satisfaction from such consumption.

This consumption orientation started giving rise to imbalances in factors life, environment, water resources, ecology, and pollution of natural resources. The shortage of good resources started rising due to faulty practices in using them. Following are few reasons which have been affecting the sustainability adversely during the $21^{\text {st }}$ century.

2.4 Root Cause of the challenges to Sustainable Development in $21^{\text {st }}$ Century.

1. Rapid economic growth achieved after globalization by most of the developing countries, has imposed considerable social costs and has become a major threat to sustainable development.

2. Detachment of humankind from nature, increasing industrial and technological development had been taking place by the evolution of the prevailing scientific materialist philosophy. The notion of limitless economic growth had fitted well into the - unlimited growth $\|$ myth of the profit-led Western world.

3. Excess Consumption: Earth takes now one year and four months to regenerate resources used in a single year. And if this continues apace, the equivalent of two Earths will be needed to support humanity's resource requirement by mid-2030. Today the big question is, "How many people that earth can sustain and at what standard of living?"

4. Increase in the Population: In 1950 Earth was taking care of 200 Crores people, today same earth is taking care of 700 Crores peoples in 2016

2.5 Corporate Social Responsibility - Concept and issues.
The presence of multinational and multiproduct companies started during the $6^{\text {th }}$ decade of 20 th century as they started operating throughout the globe. This era commenced after

the end of Second World War. This era gave a birth to the word Corporate and corporate world began to exist.

There was a good sense of businessmen for funding the social activities for benefit of members of society for a very long period in India.

However, the companies, having origin in one country and using resources of another country for their production made the issue complex. Such companies and the companies of the country were responsible for using the resources of the society and therefore, the different groups from the society started expecting in return from them.

This concept of responsibility of companies to meet these expectations should undertake certain activities for the member of the society emerged the concept of CSR.

Thus, the definition of CSR is subject to evolutionary processes as it depends on the needs of the society which are related to the welfare of the society and subject to change

from time to time.

The principle behind CSR is that, businesses take from the society and have the responsibility to give back. In majority of the cases, there were practices prevailing in the past to spend and work for the society. Tatas were discharging CSR even when the word CSR was not in existence.

In 1953, Howard Bowen's Social Responsibilities of the Businessman defined the social responsibility of businessmen as "the obligations of businessmen to pursue those policies, to make those decisions, or to follow those lines of action which are desirable in terms of the objectives and values of our society"

During the 1960s, definitions of Corporate Social Responsibility (CSR) began to spread:

Davis (1960), for example, argued that CSR refers to "businessmen's decisions and actions taken for reasons at least partially beyond the firm's direct economic or technical interest" Frederick (1960) has given the different dimensions to the concept of social responsibility. He has given the importance to public interest as compare to private interest. He advocated that all economic and human resources should be used to in the broader interest of society and public at large instead of protecting the interest of private institution and private persons. In 1984, another dimension of "Stakeholder Theory" was given by Freeman. The concept of "Corporate Citizenship" is added in the scope of Social Responsibility by Andriof and McIntosh in 2001

\section{According to World Business Council}

\begin{tabular}{|c|c|c|c|}
\hline \multicolumn{4}{|c|}{$\begin{array}{l}\text { Table 01: List of Pharmaceutical Companies arranged in } \\
\text { alphabetical manner with their order of number }\end{array}$} \\
\hline Sr. No & Name of the Company & $\begin{array}{l}\text { Company } \\
\text { code No }\end{array}$ & $\begin{array}{l}\text { Number } \\
\text { in top } 15\end{array}$ \\
\hline 1 & AurobindoPharma Limited & 1 & 2 \\
\hline 2 & Cipla Limited & 2 & 4 \\
\hline 3 & Dabar India Ltd. & 3 & 6 \\
\hline 4 & Dr.Reddy's Laboratories & 4 & 5 \\
\hline 5 & Emami Ltd. & & 13 \\
\hline
\end{tabular}




\begin{tabular}{|c|l|c|c|}
6 & GlenmarkPharma Limited & 6 & 8 \\
\hline 7 & Lupin Limited & 7 & 3 \\
\hline 8 & Piramal Enterprises Limited & 8 & 12 \\
\hline & $\begin{array}{l}\text { Sun Pharmaceutical Industries } \\
\text { Limited }\end{array}$ & 9 & 1 \\
\hline 10 & $\begin{array}{l}\text { Torrent Pharmaceuticals } \\
\text { Limited }\end{array}$ & 10 & 9 \\
\hline
\end{tabular}

"CSR is the commitment of business to contribute to sustainable economic development, working with employees, their families, the local community and society at large to improve their quality of life ${ }^{\prime 3}$

As per World Business Council for Sustainable Development, WBCSD)

In recent past, during the 2013, CSR became the part and parcel of mandate in India. This provided the legal framework for the regulation of CSR in terms of section 135 of Companies Act 2013. This divided CSR into statutory and non-statutory.

The mandate expects to report separately in CSR format (refer scheduleVII to act) about the details of the activities conducted in different sectors as prescribed and the outlay of spending on different projects.

This CSR report becomes the part and parcel of Annual Report of the company for the respective year and the information made available to different stakeholders.

This has facilitated various studies regarding CSR by providing authentic data as a secondary source of literature.

\section{OBJECTIVES:}

CSR report is mandatory to include in the annual report of the company. This fact has been facilitating the provision of availability of secondary data to the researchers and other stakeholders. This data in the form of a report is the most authentic one

With reference to CSR report, the objectives of the paper are as under.

1. From Pharmacy Sector, select the top 10 companies.

2. To read the report critically and creatively, in order to understand the broad areas in which the companies are conducting their CSR activity.

3. To enumerate the activities which fall under the broad area, which would facilitate indicatively, the domain of broad areas.

4. To analyze the presence of these companies according to the activities with reference to true spirit and connotations.

5. To establish the linkage between these goals and the nature of activities conducted by the companies and identify the gap between CSR activities and expectations of SDG. The attempt is made from the direction point of view and certainly may not be seen with the sense of magnitude of the implications.

Thus, this objective of looking at the linkage with the direction is a kind of birds review and at very primary gross level. (Refer table No 02, and 03 for details of goals and connotations)

\section{RESEARCH FRAME:}

\subsection{Research type - Descriptive}

This research is of descriptive type as it unfolds the different facts about the activities conducted under the broader domain of CSR.

\subsection{Sector - Pharmaceutical}

The pharma sector is taken because those companies are engaged in more sustainable products like Medicines and product related to health care. Rather, health care itself has the prevention value which is an integral part of human kingdom as well as animal kingdom. Their products are resulting in the lifespan of all human beings, for different age groups. Their products are consumed right from the inception and prenatal stages of a human being.

\subsection{Population}

If one considers the entities engaged in pharma business, then it is having unlimited scope. Including multi-nationals, it covers the individuals who sell Jadibutties by raising the tents on road as well as those who visit your house like Vaidus, who offer the solutions by recommending you the forest grown Vanaspities.

Considering the context of sustainability and corporate domain, the population is definite but very large because it may include all those producers right from tiny level to multi-nationals and multi-product companies in India.

\subsection{Sample frame}

Top 10 companies were considered for the purpose of this context.

\section{UNDP AND SDG GOALS AN OVERVIEW}

Sustainability and growth as well as related issues are the concern of different countries of the globe. With an increase in population, the problem like climate change, flood and such other disasters are taking place all over the world. They are so disastrous that they completely shatter the lives of human being and even to measure the loss in full terms is not possible in many cases.

As a result, i.e. the major threat to the sustainability in all areas and the world has become very vulnerable in protecting the sustainability. Therefore, United Nations Organization (UNO) has been making all out efforts with the partnership of different countries under the domain of UNDP. This program has its valuable objectives, spelt out in terms of SDGs.

Table 02 and Table 03 gave below gives the details of SDG and their connotation along with results expected and present status. 


\subsection{Sustainability Goals as Defined by UNDP as}

Table 02: UNDP SDG Goals ${ }^{4}$

\begin{tabular}{|l|l|}
\hline 1. No Poverty & 10. Reduced Inequalities \\
\hline 2. Zero Hunger & 11. Sustainable Cities and Communities \\
\hline 3. Good Health and Well Being & 12. Responsible Consumption and Production \\
\hline 4. Quality Education. & 13. Climate Action \\
\hline 5. Gender Equality & 14. Life Below Water \\
\hline 6. Clean Water and Sanitation & 15. Life on Land \\
\hline 7. Affordable and Clean Energy & 16. Peace, Justice and Strong Institution. \\
\hline 8. Decent Work and Economic Growth & 17. Partnership For Goals. \\
\hline 9. Industry Innovation and Infrastructure & \\
\hline
\end{tabular}

Table 03: UNDP SDG Goals: Result Expected and Present Situation ${ }^{5}$

\begin{tabular}{|c|c|c|c|}
\hline Sr.No & SDG Goal & Result Expected & Problem and Present Situation \\
\hline 1 & No Poverty & End extreme poverty in all forms by 2030 & $\begin{array}{l}\text { More than } 800 \text { million people around the world still live on } \\
\text { income less than Rs. } 100 \text { per day }\end{array}$ \\
\hline 2 & Zero Hunger & $\begin{array}{l}\text { End hunger, achieve food security and } \\
\text { improved nutrition and promote } \\
\text { sustainable agriculture }\end{array}$ & $\begin{array}{l}\text { Imagine a world where everyone has access to sufficient and } \\
\text { nutritious food all year round. Together, we can make that a } \\
\text { reality by } 2030 \text {. }\end{array}$ \\
\hline 3 & $\begin{array}{l}\text { Good Health } \\
\text { and Well Being }\end{array}$ & $\begin{array}{l}\text { Ensure healthy lives and promote well } \\
\text { being for all at all ages. }\end{array}$ & $\begin{array}{l}\text { We all know how important it is to be in good health. Our } \\
\text { health affects everything from how much we enjoy life to what } \\
\text { work we can perform. }\end{array}$ \\
\hline 4 & $\begin{array}{l}\text { Quality } \\
\text { Education }\end{array}$ & $\begin{array}{l}\text { Ensure inclusive and equitable quality } \\
\text { education and promote lifelong learning } \\
\text { opportunities for all }\end{array}$ & $\begin{array}{l}\text { First, the bad news on education. Poverty, armed conflict and } \\
\text { other emergencies keep many, many kids around the world } \\
\text { out of school. In fact, kids from the poorest households are } \\
\text { four times more likely to be out of school than those of the } \\
\text { richest households }\end{array}$ \\
\hline 5 & $\begin{array}{l}\text { Gender } \\
\text { Equality }\end{array}$ & $\begin{array}{l}\text { Achieve gender equality and empower all } \\
\text { women and girls }\end{array}$ & $\begin{array}{l}\text { The Sustainable Development Goals aim to ensure that there } \\
\text { is an end to discrimination against women and girls } \\
\text { everywhere. }\end{array}$ \\
\hline 6 & $\begin{array}{l}\text { Clean Water } \\
\text { and Sanitation }\end{array}$ & $\begin{array}{l}\text { Ensure availability and sustainable } \\
\text { management of water and sanitation for all }\end{array}$ & $\begin{array}{l}\text { Everyone on earth should have access to safe and affordable } \\
\text { drinking water. That's the goal for } 2030\end{array}$ \\
\hline 7 & $\begin{array}{l}\text { Affordable } \\
\text { Clean Energy }\end{array}$ & $\begin{array}{l}\text { Ensure access to affordable, reliable, } \\
\text { sustainable and modern energy for all }\end{array}$ & $\begin{array}{l}\text { Between } 1990 \text { and } 2010 \text {, the number of people with access } \\
\text { to electricity increased by } 1.7 \text { billion. That's progress to be } \\
\text { proud of. And yet as the world's population continues to rise, } \\
\text { still more people will need cheap energy to light their homes } \\
\text { and streets, use phones and computers, and do their everyday } \\
\text { business. How we get that energy is at issue; fossil fuels and } \\
\text { greenhouse gas emissions are making drastic changes in the } \\
\text { climate, leading to big problems on every continent }\end{array}$ \\
\hline 8 & $\begin{array}{l}\text { Decent work } \\
\text { and Economic } \\
\text { Growth }\end{array}$ & $\begin{array}{l}\text { Promote sustained inclusive and } \\
\text { sustainable economic growth, full and } \\
\text { productive employment and decent work } \\
\text { for all }\end{array}$ & $\begin{array}{l}\text { An important part of economic growth is that people have } \\
\text { jobs that pay enough to support themselves and their families }\end{array}$ \\
\hline 9 & $\begin{array}{l}\text { Industry } \\
\text { Innovation and } \\
\text { Infrastructure }\end{array}$ & $\begin{array}{l}\text { Build resilient infrastructure, promote } \\
\text { inclusive and sustainable industrialization } \\
\text { and foster innovation }\end{array}$ & $\begin{array}{l}\text { And yet four billion people have no way of getting online, the } \\
\text { vast majority of them in developing countries. }\end{array}$ \\
\hline 10 & $\begin{array}{l}\text { Reduced } \\
\text { Inequalities }\end{array}$ & $\begin{array}{l}\text { Reduce inequality within and among } \\
\text { countries }\end{array}$ & $\begin{array}{l}\text { Income inequality is a global problem that requires global } \\
\text { solutions. }\end{array}$ \\
\hline
\end{tabular}


Examination of UNDP Goal Orientation of CSR Activities towards Sustainable Development by Corporates in Pharmacy Sector

\begin{tabular}{|c|c|c|c|}
\hline Sr.No & SDG Goal & Result Expected & Problem and Present Situation \\
\hline 11 & $\begin{array}{l}\text { Sustainable } \\
\text { Cities and } \\
\text { Communities }\end{array}$ & $\begin{array}{l}\text { Make cities and human settlements } \\
\text { inclusive, safe resilient and sustainable }\end{array}$ & $\begin{array}{l}\text { If you're like most people, you live in a city. More than half } \\
\text { the world's population now lives in cities, and that figure will } \\
\text { go to about two-thirds of humanity by the year } 2050 \text {. Cities } \\
\text { are getting bigger. In } 1990 \text { there were ten "mega-cities" with } \\
10 \text { million inhabitants or more. In } 2014 \text {, there were } 28 \text { mega- } \\
\text { cities, home to } 453 \text { million people. }\end{array}$ \\
\hline 12 & $\begin{array}{l}\text { Responsible } \\
\text { Consumption } \\
\text { and Pattern }\end{array}$ & $\begin{array}{l}\text { Ensure sustainable consumption and } \\
\text { production pattern. }\end{array}$ & $\begin{array}{l}\text { Some people use a lot of stuff, and some people use very } \\
\text { little - in fact, a big share of the world population is consuming } \\
\text { too little to meet even their basic needs. Instead, we can have } \\
\text { a world where everybody gets what they need to survive and } \\
\text { thrive. And we can consume in a way that preserves our } \\
\text { natural resources so that our children can enjoy them, and } \\
\text { their children and their children after that. }\end{array}$ \\
\hline 13 & Climate Action & $\begin{array}{l}\text { Take urgent action to combat climate } \\
\text { change and its impacts. }\end{array}$ & $\begin{array}{l}\text { Every country in the world is seeing the drastic effects of } \\
\text { climate change, some more than others. On average, the } \\
\text { annual losses just from earthquakes, tsunamis, tropical } \\
\text { cyclones and flooding count in the hundreds of billions of } \\
\text { dollars }\end{array}$ \\
\hline 14 & $\begin{array}{l}\text { Life below } \\
\text { Water }\end{array}$ & $\begin{array}{l}\text { Conserve and sustainably use the Oceans, } \\
\text { Seas and Marine Resources for } \\
\text { sustainable Development. }\end{array}$ & $\begin{array}{l}\text { The oceans make human life possible. Their temperature, their } \\
\text { chemistry, their currents, their life forms. For one thing, more } \\
\text { than } 3 \text { billion people depend on marine and coastal diversity } \\
\text { for their livelihoods. But today we are seeing nearly a third of } \\
\text { the world's fish stocks overexploited. That's not a sustainable } \\
\text { way of life. Even people who live nowhere near the ocean } \\
\text { can't live without it. Oceans absorb about } 30 \text { percent of the } \\
\text { carbon dioxide that humans produce; but we're producing } \\
\text { more carbon dioxide than ever before and that makes the } \\
\text { oceans more acidic- } 26 \% \text { more, since the start of the } \\
\text { industrial revolution. Our trash doesn't help either-13,000 } \\
\text { pieces of plastic litter on every square kilometer of ocean. }\end{array}$ \\
\hline 15 & Life on Land & $\begin{array}{l}\text { Protest, Restore and Promote sustainable } \\
\text { use of terrestrial ecosystem sustainably } \\
\text { manage forests, combat desertification, } \\
\text { and halt and reserve land degradation and } \\
\text { halt biodiversity loss. }\end{array}$ & $\begin{array}{l}\text { Humans and other animals rely on other forms of life on land } \\
\text { for food, clean air, clean water, and as a means of combating } \\
\text { climate change. Plant life makes up } 80 \% \text { of the human diet. } \\
\text { Forests, which cover } 30 \% \text { of the Earth's surface, help keep } \\
\text { the air and water clean and the Earth's climate in balance. } \\
\text { That's not to mention they're home to millions of animal } \\
\text { species. But the land and life on it are in trouble. Arable land is } \\
\text { disappearing } 30 \text { to } 35 \text { times faster than it has historically. } \\
\text { Deserts are spreading. Animal breeds are going extinct }\end{array}$ \\
\hline 16 & $\begin{array}{l}\text { Peace, Justice } \\
\text { and Strong } \\
\text { Institutions }\end{array}$ & $\begin{array}{l}\text { Promote peaceful and inclusive societies } \\
\text { for sustainable development, provide } \\
\text { access to justice for all and build effective, } \\
\text { accountable and inclusive institution al all } \\
\text { levels. }\end{array}$ & $\begin{array}{l}\text { How can a country develop-how can people eat and teach } \\
\text { and learn and work and raise families-without peace? And } \\
\text { how can a country have peace without justice, without human } \\
\text { rights, without government based on the rule of law? Some } \\
\text { parts of the world enjoy relative peace and justice, and may } \\
\text { come to take it for granted. Other parts seem to be plagued } \\
\text { by armed conflict, crime, torture and exploitation, all of which } \\
\text { hinders their development }\end{array}$ \\
\hline 17 & $\begin{array}{l}\text { Partnership for } \\
\text { Goals }\end{array}$ & $\begin{array}{l}\text { Strengthen the means of implementation } \\
\text { and revitalize the global partnership for } \\
\text { sustainable development. }\end{array}$ & $\begin{array}{l}\text { The Sustainable Development Goals are pretty big to-do list, } \\
\text { don't you think? In fact, it's so big, you may just want to } \\
\text { throw your hands up in the air. "Forget it! Can't be done! } \\
\text { Why even try!" But we've got a lot going for us. The world is } \\
\text { more interconnected today than ever before, thanks to the } \\
\text { internet, travel and global institutions. There's a growing } \\
\text { consensus about the need to work together to stop climate } \\
\text { change. And the Sustainable Development Goals are no small } \\
\text { matter either }\end{array}$ \\
\hline
\end{tabular}




\subsection{UNDP in India6}

(Source:

https://www.in.undp.org/content/india/en/home/about-us.ht $\underline{\mathrm{ml}})$

UNDP has worked in India since 1951 in almost all areas of human development, from systems and institutional strengthening to inclusive growth and sustainable livelihoods, as well as sustainable energy, environment and resilience. UNDP's programs continue to fully integrate a global vision for catalytic change with India's national priorities.

With over 30 projects on the ground in almost every state, today UNDP India works towards Sustainable Development Goals by transforming traditional models to do development differently. In a rapidly changing global environment, the work of UNDP and the broader UN family aligns with the Government of India's new national development vision, India 2030, and builds upon the Sustainable Development Goals. UNDP India's country program for 2018-2022 has three major focus areas:

$\checkmark$ Inclusive growth

$\checkmark$ Environment and energy

$\checkmark$ Strengthening systems and institutions

These are supported by a framework of renewed partnerships and blended finance solutions, a pool of financial and technical resources for greater impact and scale, and South-South expertise.

The features of the efforts so far put in by India and UNDP partnership have rendered the following:

\begin{tabular}{|c|l|}
\hline $74 \%$ & Adulty Litercy Rate \\
\hline $12 \%$ & Share of women in Parliament \\
\hline $125 \mathrm{Rank}$ & Rank on Gender Inequality Index \\
\hline $21.54 \%$ & Proportion ofland area covered by forest \\
\hline $1.73 \mathrm{MT}$ & CO2 emissions per capita (metric tons) \\
\hline $79 \%$ & Enrolment in undergraduate education \\
\hline 0.624 & Human Development Index (2016) \\
\hline 1.3 & billion population \\
\hline 1861.50 & per capita (in current Prices, USD) \\
\hline
\end{tabular}

In nutshell, SDGs are given due attention by Indian policy makers and the government with rational gravity.

\section{METHODOLOGY}

For the purpose of data, the paper completely relies on secondary data in terms CSR reports, contained in Annual Reports of top 10 companies for the accounting year 2018-2019.

The data is absolute in its nature as regards authenticity of the data as these reports are a public document and they are submitted to different top government authorities. They are meant for rendering true and correct information to all kind of stakeholders.

From these annual reports, a report of each company is scrutinized critically and following steps were followed.

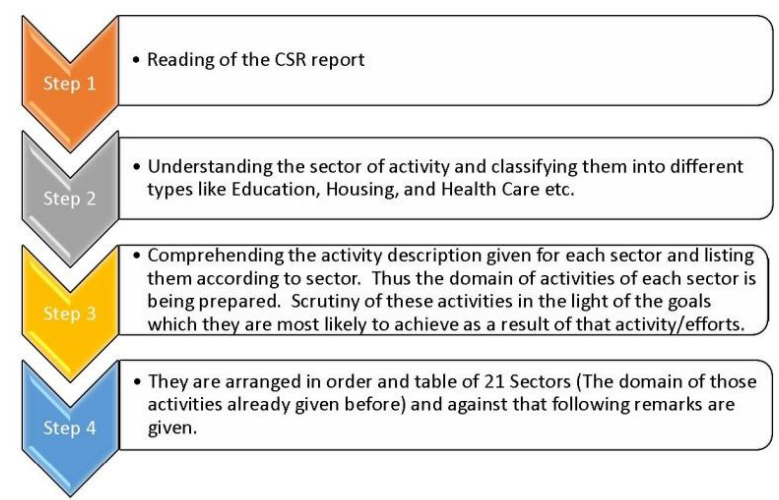

It is presented in tabular form and the description of the table is as under:

Column 1: Indicates serial number in Roman

Column 2: Contains the heading of the domain

Column 3 to 20 indicates the heading of the goals.

If it has a direction towards the achievement of any of the goals even in slightest indirect way, then it is marked with "YES". If it is not so then, against that it is Kept Blank Inferences are presented by keeping the table details at a glance.

(In order to make the entire table, available at a glance, the goals are given in abbreviation form. The readers are requested to refer goals in full form given at the beginning of the table.)

\section{DATA ANALYSIS}

The data related to expenditure on CSR is seen from the view point of the turnover, \% of CSR spending and Budgeted to Actual Spending.

\subsection{Sales Turnover and CSR Expenditure}

The following table represents the turnover $\%$ to spending on CSR activities in respect of accounting year 2018-19. 
Examination of UNDP Goal Orientation of CSR Activities towards Sustainable Development by Corporates in Pharmacy Sector

Table 3: Turnover and Expenditure on CSR Activities (2018-19)

(Rs. In Millions)

\begin{tabular}{|c|l|r|r|r|}
\hline $\begin{array}{c}\text { Sr. } \\
\text { No }\end{array}$ & \multicolumn{1}{|c|}{ Name of the Company } & Turnover & \multicolumn{1}{c|}{$\begin{array}{c}\text { CSR } \\
\text { Expenditure }\end{array}$} & $\begin{array}{c}\text { \% to } \\
\text { Turnover }\end{array}$ \\
\hline 01 & AurobindoPharma Limited & 164,990 & 467.73 & 0.28 \\
\hline 02 & Cipla Limited & 155,770 & 334.24 & 0.21 \\
\hline 03 & Dabar India Ltd. & 87,343 & 263.50 & 0.30 \\
\hline 04 & Dr. Reddy's Laboratories & 144,360 & 261.54 & 0.18 \\
\hline 05 & Emami Ltd. & 26,930 & 79.65 & 0.30 \\
\hline 06 & GlenmarkPharma Limited & 91,860 & 311.49 & 0.34 \\
\hline 07 & Lupin Limited & 159,550 & 379.50 & 0.24 \\
\hline 08 & Piramal Enterprises Limited & 43,220 & 311.80 & 0.72 \\
\hline 09 & Sun Pharmaceutical Industries Limited & 277,280 & 39.34 & 0.01 \\
\hline 10 & Torrent Pharmaceuticals Limited & 63,010 & 264.50 & 0.42 \\
\hline & Total & 1210,31 & 2713.39 & 0.22 \\
& & 3 & & \\
\hline
\end{tabular}

\section{INFERENCES}

1. The highest $\%$ is of Piramal Enterprises Limited.

2. Despite having the highest turnover amongst above 10 companies, Sun Pharmaceutical Industries Limited, the spending on CSR activities is the lowest. It is $0.01 \%$.

3. The range of spending is excepting Sun Pharmaceutical Industries Limited, the range is between $0.18 \%$ to $0.72 \%$

\section{CONCLUSION}

1. As CSR Expenditure is linked to profits (2\% of last three years average profit), when compared to turnover, the $\%$ is extremely marginal.

2. Sun Pharmaceutical Industries Limited is incurring losses for last 3 years. Despite these losses, the company is spending on CSR activities and showing the real spirit behind CSR concept.

\subsection{Comparison of CSR Expenditure: Budget Vs Actual}

Table No 04: Composition of Spending on CSR

(Rs. In Millions)

\begin{tabular}{|c|c|c|c|c|c|c|}
\hline Sr. & Name of the Company & Turnover & \multicolumn{4}{|c|}{ CSR Expenditure } \\
\hline & & & Actual & Budget & Unspent & Overspent \\
\hline 01 & AurobindoPharma Limited & 164,990 & 467.73 & 467.73 & 0.00 & 0.00 \\
\hline 02 & Cipla Limited & 155,770 & 334.24 & 889.70 & 555.46 & 0.00 \\
\hline 03 & Dabar India Ltd. & 87,343 & 263.50 & 260.00 & 0.00 & 3.50 \\
\hline 04 & Dr. Reddy's Laboratories & 144,360 & 261.54 & 271.68 & 10.04 & 0.00 \\
\hline 05 & Emami Ltd. & 26,930 & 79.65 & 79.10 & 0.00 & 0.55 \\
\hline 06 & GlenmarkPharma Limited & 91,860 & 311.49 & 311.49 & 0.00 & 0.00 \\
\hline 07 & Lupin Limited & 159,550 & 379.50 & 322.30 & 0.00 & 57.20 \\
\hline 08 & Piramal Enterprises Limited & 43,220 & 311.80 & 385.90 & 74.10 & 0.00 \\
\hline 09 & $\begin{array}{c}\text { Sun Pharmaceutical Industries } \\
\text { Limited }\end{array}$ & 277,280 & 39.34 & 51.56 & 12.22 & 0.00 \\
\hline 10 & $\begin{array}{l}\text { Torrent Pharmaceuticals } \\
\text { Limited }\end{array}$ & 63,010 & 264.50 & 273.50 & 9.00 & 0.00 \\
\hline & Total & $\begin{array}{l}1210,31 \\
3\end{array}$ & 2713.39 & 3312.96 & 660.82 & 61.25 \\
\hline
\end{tabular}

\section{Inferences}

1. There are three Companies like Sr. No 03, 05 and 07, have shown that they have spent more than their budget. Overspent amount is very marginal i.e. $1.84 \%$

2. It should be appreciated that Lupin Limited has spent $17.75 \%$ above the budget.

3. There are five companies (Sr.No. 02,04,08,09 and 10), have shown that they have spent less than their budget.

4. The amount of total unspent value is nearly $20 \%$. Amongst these Companies Cipla Limited have not spent to the tune of $62.43 \%$ which is very high percentage. 


\subsection{Composition of Spending on Domain Sector}

Table No 05: Composition of spending on sector domain.

Rs. in Million

\begin{tabular}{|c|l|r|r|}
\hline \multicolumn{1}{|c|}{ Composition of Spending on Sector Domain } \\
\hline Sr.No & \multicolumn{1}{|c|}{ Sector } & $\begin{array}{c}\text { Actual } \\
\text { Expenditure }\end{array}$ & $\begin{array}{c}\text { Expenditure } \\
\text { in \% }\end{array}$ \\
\hline I & Promoting Education, Vocational Training and Vocational Skill Development & 636.32 & $23.45 \%$ \\
\hline II & Promoting Preventive healthcare and sanitation, & $1,021.93$ & $37.66 \%$ \\
\hline III & Making available safe drinking water & 9.00 & $0.33 \%$ \\
\hline IV & Eradicating Hunger, Poverty, malnutrition & 254.90 & $9.39 \%$ \\
\hline V & Promote rural sports, Nationally recognized sports & 67.30 & $2.48 \%$ \\
\hline VI & Rural Development, Environmental Sustainability, Ecological Balance & 238.41 & $8.79 \%$ \\
\hline VII & Setting up of Old Age Homes & 2.00 & $0.07 \%$ \\
\hline VIII & Environmental Sustainability and Ecological Balance & 33.42 & $1.23 \%$ \\
\hline IX & Animal Welfare & 5.10 & $0.19 \%$ \\
\hline X & Infrastructure Support & 1.70 & $0.06 \%$ \\
\hline XI & Reduction in inequality & 0.32 & $0.01 \%$ \\
\hline XII & Social and Economic Development & 223.10 & $8.22 \%$ \\
\hline XIII & Livelihood Enhancement Projects & 136.41 & $5.03 \%$ \\
\hline XIV & Capacity Building & $\mathbf{2 , 7 1 3 . 3 9}$ & $\mathbf{1 0 0 . 0 0 \%}$ \\
\hline XV & Promoting Art, Culture and Dance form & 11.78 & 0.76 \\
\hline XVI & Disaster Management & 4.53 & $0.10 \%$ \\
\hline XVII & Women Empowerment & $0.17 \%$ \\
\hline XVIII & Administrative Overheads & $0.04 \%$ \\
\hline & Total: & & $2.33 \%$ \\
\hline
\end{tabular}

\section{Conclusion}

By virtue of format prescribed by the statute, the reliable disclosures regarding CSR figures is being available to different stakeholders.

\section{Inferences:}

1. The sectors like Education and Health Care have maximum number of activities. It seems that the companies have given the preference to these sectors as their core business is related to healthcare.

2 . The spending composition shows that nearly $62 \%$ is made on Education and Healthcare.

3. Other sectors i.e. eradicating poverty and hunger as well as Rural Development projects constitute nearly $10 \%$ each.

4. Remaining 7 sectors have very negligible spending.

5. The administrative expenses for the project implementation for all companies is $2.43 \%$ where as it is in the range of $1 \%$ to $5 \%$,

\section{Conclusion}

The companies are more interested to work for promotion of Education and Healthcare including preventive one.

\section{DOMAIN SECTOR ACTIVITY DETAILS}

There are in all 17 domain sectors in which the companies conduct various CSR activities and administrative overheads are reported separately. According to analysis of the 10 Companies, the activities conducted under each sector are brought at one place. This is an indicative list of activities. The activities represent an aggregate view of 10 Companies.

It is essential to understand that for a particular sector which kind of activities are being conducted by the different pharma companies, are brought at one place in order to

develop the perspective about the sphere of the reader.

(This exercise would useful for those who desire to conduct some activities in some sector, and then they would understand the different activities with their nature which they can adopt according to their priority and ability to spend.) 
Examination of UNDP Goal Orientation of CSR Activities towards Sustainable Development by Corporates in Pharmacy Sector

\begin{tabular}{|c|c|}
\hline Sr.No. & Domain Sector/ Activity Details \\
\hline I & Healthcare \\
\hline 1 & Promoting Preventive healthcare and sanitation \\
\hline 2 & Cipla Palliative Care and Training Centre \\
\hline 3 & Healthcare services to community including hospitals, \\
\hline Sr.No. & Domain Sector/ Activity Details \\
\hline 4 & Building Sanitation Blocks \\
\hline 5 & Help through ICDS center \\
\hline 6 & $\begin{array}{c}\text { Dil Se Dua' program to fight malnutrition among children } \\
\text { and also involved general public }\end{array}$ \\
\hline 7 & $\begin{array}{l}\text { Immune India awareness program among school going } \\
\text { children. }\end{array}$ \\
\hline 8 & Wellness Centre to treat people \\
\hline 9 & $\begin{array}{l}\text { Programs for addressing Health care needs of poor and } \\
\text { needy }\end{array}$ \\
\hline 10 & Oral hygiene awareness Camps in Schools \\
\hline 11 & Programmers for Safe \& Nutritious Drive with FSSIA \\
\hline 12 & Ayurvedic Health OPDs for Rag Picker \\
\hline 13 & Programmers for Diabetes Prevention and Management \\
\hline 14 & Psychological health support \\
\hline 15 & Health Intervention program \\
\hline 16 & Distribution of medicine to needy children \\
\hline 21 & $\begin{array}{l}\text { Rehabilitation \& Care of those with chemical Dependency } \\
\text { and HIVAIDS, including relevant Statistical Research }\end{array}$ \\
\hline 22 & $\begin{array}{c}\text { Building and implementing integrated Electronic Medical } \\
\text { Records Platform Software }\end{array}$ \\
\hline 23 & REACH - pediatric Healthcare program \\
\hline II & Education \\
\hline 1 & Promoting Education (Details of Activities not given \\
\hline 2 & $\begin{array}{l}\text { Mobile Service Van, Scholarships, E learning, } \\
\text { Infrastructural Support, }\end{array}$ \\
\hline 3 & $\begin{array}{l}\text { Vocational training, Skill Development, Meritorious } \\
\text { Awards, }\end{array}$ \\
\hline 4 & Promoting Education in Government Schools, \\
\hline 5 & Education awareness program \\
\hline 6 & Training and skill enhancement \\
\hline 7 & $\begin{array}{l}\text { Programs for promoting education through NFEs, } \\
\text { Remedial Classes }\end{array}$ \\
\hline 8 & $\begin{array}{l}\text { School Support programs like renovation, sanitary blocks, } \\
\text { benches, chairs etc }\end{array}$ \\
\hline 9 & Vocational Training to Women and Villagers \\
\hline 10 & $\begin{array}{l}\text { Programs for Adult Literacy Centers and Support to Self } \\
\text { Help Groups }\end{array}$ \\
\hline 11 & DRF education programs \\
\hline 12 & Supporting and subsidizing quality education in low \\
\hline
\end{tabular}

\begin{tabular}{|c|c|}
\hline & income groups. \\
\hline 13 & Quality education program in Government Schools \\
\hline 14 & Quality education in science \\
\hline 15 & Chair in Chemical Science \\
\hline Sr.No. & Domain Sector/ Activity Details \\
\hline 16 & $\begin{array}{l}\text { Scholarship/ Assistance to Students and Education support } \\
\text { program }\end{array}$ \\
\hline 17 & Rural Education program \\
\hline 18 & Establishment of educational Training Centre \\
\hline 19 & Establishment of educational Training Centre \\
\hline III & Making available safe drinking water \\
\hline 1 & Making available of Safe Drinking Water \\
\hline 2 & Drinking water project \\
\hline IV & $\begin{array}{c}\text { Eradicating Hunger, Poverty, malnutrition and promoting } \\
\text { Preventing health care }\end{array}$ \\
\hline 1 & $\begin{array}{c}\text { Eradicating Hunger, Poverty, malnutrition and promoting } \\
\text { Preventing health care }\end{array}$ \\
\hline 2 & $\begin{array}{c}\text { Disaster Relief (Medical Relief, Basic Assistance, } \\
\text { Material, Medical Camps, Child } \\
\text { Friendly Spaces }\end{array}$ \\
\hline 3 & $\begin{array}{l}\text { Sanitation Drive to provide easy access to and Sanitation } \\
\text { facilities in Rural Hospitals }\end{array}$ \\
\hline 4 & Programs to meet nutrition needs of poor and needy \\
\hline 5 & Support to Independent NGOs for Nutrition initiative \\
\hline $\mathrm{V}$ & $\begin{array}{c}\text { Training to promote rural sports, nationally recognized } \\
\text { sports }\end{array}$ \\
\hline 1 & Promotion of Rural Sports \\
\hline 2 & Sports Training Center \\
\hline 3 & Transform the Ecosystem of Swimming in India \\
\hline VI & $\begin{array}{l}\text { Rural Development Projects, Environmental } \\
\text { Sustainability, Ecological Balance }\end{array}$ \\
\hline 1 & Rural development and infrastructure around units \\
\hline 2 & Infrastructure around unit's cold storage for better crop, \\
\hline 3 & Development and Maintenance of Public Parks \\
\hline 4 & Pond deepening Program \\
\hline 5 & Environment Conservation program \\
\hline 6 & $\begin{array}{l}\text { Protect rare herbs and plants which are on the way to } \\
\text { vanish on the earth. }\end{array}$ \\
\hline 7 & $\begin{array}{l}\text { Developing \& Supplying seed and seedlings to local } \\
\text { farmers }\end{array}$ \\
\hline 8 & Tree plantation Drive \\
\hline 9 & Promotion of Solar Energy \\
\hline
\end{tabular}




\begin{tabular}{|c|c|}
\hline 10 & Water Conservation Project in Rajasthan + Water ATM \\
\hline 11 & $\begin{array}{l}\text { Consumer Waste initiative for Multi-Layer Plastic (MLP) } \\
\text { waste disposal }\end{array}$ \\
\hline VII & Social and Economic Development \\
\hline 1 & Rural Support Program (Details not given) \\
\hline Sr.No. & Domain Sector/ Activity Details \\
\hline 2 & Learn and Earn Program \\
\hline VIII & Livelihood Enhancement Projects \\
\hline 1 & $\begin{array}{l}\text { Livelihood Program for Youth and People with Disability } \\
\text { (PWD) program }\end{array}$ \\
\hline 2 & MITRA - Agricultural program \\
\hline 3 & $\begin{array}{l}\text { Employment enhancing vocation skills and Livelihood } \\
\text { enhancement program }\end{array}$ \\
\hline 4 & Farmer field school project \\
\hline IX & Animal Welfare \\
\hline 1 & Animal welfare and Environment program \\
\hline $\mathrm{X}$ & Infrastructure Support \\
\hline 1 & $\begin{array}{c}\text { Development and support infrastructure like furniture, } \\
\text { buildings, boards etc }\end{array}$ \\
\hline 2 & Health Care Infrastructure Development \\
\hline XI & Reduction in inequality \\
\hline 1 & Support for child victim rescue vehicle \\
\hline XII & Social and Economical Development \\
\hline 1 & Rural Support Program \\
\hline 2 & Learn and Earn Program \\
\hline XIII & Livelihood Enhancement Projects \\
\hline 1 & $\begin{array}{c}\text { Livelihood programs for youth and Livelihood programs } \\
\text { for youth and people with disability }\end{array}$ \\
\hline
\end{tabular}

\begin{tabular}{|c|c|}
\hline 2 & MITRA - Agricultural program \\
\hline 3 & Farmer field school project \\
\hline XIV & Capacity Building \\
\hline 1 & $\begin{array}{c}\text { Expenses incurred on capacity building including } \\
\text { overheads. }\end{array}$ \\
\hline XV & Promoting Art, Culture and Dance. \\
\hline 1 & $\begin{array}{c}\text { Promoting Art and Culture by supporting Art, Dance form } \\
\text { training and supporting Social infrastructure. }\end{array}$ \\
\hline XVI & Disaster Management \\
\hline 1 & $\begin{array}{c}\text { Disaster Management Program and Support during natural } \\
\text { calamities. }\end{array}$ \\
\hline XVII & Women Empowerment \\
\hline 1 & Operating a Rural BPO \& providing livelihood to Women \\
\hline
\end{tabular}

\section{LINKAGE OF CSR ACTIVITIES IN DIRECTIONAL SENSE TO SDGS}

The activities of CSR lead to different benefits to different sections of the society. The context is related to sustainability and growth.

The premise behind the achievement of sustainability goals is that, because of accomplishment in holistic way shall be conducive in generation of the growth in different sectors as an output. Thus, their achievement is surging engine for the GROWTH.

With reference to UNDP goals, a comparison is made on the parameters that whether conducting the activities in a particular sector will lead to progressing towards the achievement of above goals.

For the purpose a table is presented below and under each goal, if it is positive towards furtherance of accomplishment of those goals, then it is marked with "YES" remark. If it is not so, then it is Kept Blank.

This exercise is made to understand the direction of outcome of CSR activities collectively of the 10 companies.

Please, read the table with reference to following full forms.

\begin{tabular}{|c|c|c|}
\hline $\begin{array}{c}\text { Sr. } \\
\text { No }\end{array}$ & $\begin{array}{c}\text { AB } \\
\mathbf{R}\end{array}$ & Full Form \\
\hline 01 & NP & No Poverty \\
\hline 02 & ZH & Zero Hunger \\
\hline 03 & $\begin{array}{c}\text { CH } \\
\text { GB }\end{array}$ & $\begin{array}{c}\text { Good Health and } \\
\text { Weing }\end{array}$ \\
\hline 04 & QE & $\begin{array}{c}\text { Quality } \\
\text { Education }\end{array}$ \\
\hline 05 & GE & \begin{tabular}{c} 
Gender Equality \\
\hline 06
\end{tabular} \\
\hline CW & $\begin{array}{c}\text { Clean Water and } \\
\text { Sanitation }\end{array}$ \\
\hline
\end{tabular}

\begin{tabular}{|c|c|c|}
\hline $\begin{array}{c}\text { Sr. } \\
\text { No }\end{array}$ & $\begin{array}{c}\text { AB } \\
\mathbf{R}\end{array}$ & \multicolumn{1}{|c|}{ Full Form } \\
\hline 07 & ACE & $\begin{array}{c}\text { Affordable Clean } \\
\text { Energy }\end{array}$ \\
\hline 08 & $\begin{array}{c}\text { DW } \\
\text { EG }\end{array}$ & $\begin{array}{c}\text { Decent Work and } \\
\text { Economic Growth }\end{array}$ \\
\hline 09 & I II & $\begin{array}{c}\text { Industry } \\
\text { Innovation } \\
\text { Infrastru. }\end{array} \quad$ and \\
\hline 10 & RI & $\begin{array}{c}\text { Reduced } \\
\text { Inequalities }\end{array}$ \\
\hline 11 & SCC & $\begin{array}{c}\text { Sustainable Cities } \\
\text { and Communities }\end{array}$ \\
\hline 12 & RCP & $\begin{array}{c}\text { Resp. Cons. And } \\
\text { Production }\end{array}$ \\
\hline
\end{tabular}

\begin{tabular}{|c|c|c|}
\hline $\begin{array}{c}\text { Sr. } \\
\text { No }\end{array}$ & $\begin{array}{c}\text { A } \\
\text { BR }\end{array}$ & Full Form \\
\hline 13 & $\begin{array}{c}\text { C } \\
\text { A }\end{array}$ & Climate Action \\
\hline 14 & $\begin{array}{c}\text { L } \\
\text { BW }\end{array}$ & $\begin{array}{c}\text { Life } \\
\text { Water }\end{array}$ \\
\hline 15 & LL & Life on Land \\
\hline 16 & $\begin{array}{c}\text { PJ } \\
\text { SI }\end{array}$ & $\begin{array}{c}\text { Peace, Justice \& } \\
\text { Strong Instituti. }\end{array}$ \\
\hline 17 & P & $\begin{array}{c}\text { Partnership for } \\
\text { Growth }\end{array}$ \\
\hline & G & \\
\hline
\end{tabular}


Composition of area wise aggregate activities leading to resulting in the accomplishment of Sustainability Goals

\begin{tabular}{|c|c|c|c|c|c|c|c|c|c|c|c|c|c|c|c|c|c|c|}
\hline Sr.No & Sector/Goals & $\mathrm{np}$ & $\mathrm{zh}$ & $\begin{array}{l}\text { gh } \\
\text { wb }\end{array}$ & qe & ge & $\mathrm{cws}$ & ace & $\begin{array}{l}\mathrm{dw} \\
\mathrm{EG} \\
\end{array}$ & i ii & ri & $\mathrm{SCC}$ & $\mathrm{RCP}$ & CA & LBW & $\mathrm{LL}$ & $\begin{array}{l}\mathrm{PJ} \\
\mathrm{SI} \\
\end{array}$ & PG \\
\hline & & 1 & 2 & 3 & 4 & 5 & 6 & 7 & 8 & 9 & 10 & 11 & 12 & 13 & 14 & 15 & 16 & 17 \\
\hline I & $\begin{array}{l}\text { Education, VT } \\
\text { and SD }\end{array}$ & & & $\mathrm{Y}$ & & $\mathrm{Y}$ & & & $\mathrm{Y}$ & $\mathrm{Y}$ & & & $\mathrm{Y}$ & & & & Y & \\
\hline II & $\begin{array}{l}\text { Preventive } \\
\text { Healthcare } \\
\end{array}$ & & & $\mathrm{Y}$ & & & $\mathrm{Y}$ & & $\mathrm{Y}$ & & & $\mathrm{Y}$ & $\mathrm{Y}$ & & & & & \\
\hline III & $\begin{array}{l}\text { Safe Drinking } \\
\text { water }\end{array}$ & & & $\mathrm{Y}$ & & & $\mathrm{Y}$ & & $\mathrm{Y}$ & & & & & & & & & \\
\hline IV & $\begin{array}{l}\text { Eradicating } \\
\text { Poverty ** }\end{array}$ & $\mathrm{Y}$ & $\mathrm{Y}$ & $\mathrm{Y}$ & & & $\mathrm{Y}$ & & $\mathrm{Y}$ & & $\mathrm{Y}$ & & & & & & $\mathrm{Y}$ & \\
\hline $\mathrm{V}$ & $\begin{array}{l}\text { Rural Sports } \\
\text { Promotion }\end{array}$ & & & & $\mathrm{Y}$ & & & & & & & $\mathrm{Y}$ & & & & & & \\
\hline VI & $\begin{array}{l}\text { Rural Develop } \\
\text { Projects }\end{array}$ & Y & Y & $\mathrm{Y}$ & & & Y & $\mathrm{Y}$ & Y & $\mathrm{Y}$ & & Y & $\mathrm{Y}$ & & & & & \\
\hline VII & $\begin{array}{c}\text { Old Age } \\
\text { Homes }\end{array}$ & & & & & & & & & & & $\mathrm{Y}$ & & & & & & \\
\hline VIII & $\begin{array}{c}\text { Environment } \\
\text { Balance }\end{array}$ & & & $\mathrm{Y}$ & & & $\mathrm{Y}$ & $\mathrm{Y}$ & $\mathrm{Y}$ & & & $\mathrm{Y}$ & $\mathrm{Y}$ & $\mathrm{Y}$ & $\mathrm{Y}$ & $\mathrm{Y}$ & & \\
\hline IX & $\begin{array}{c}\text { Animal } \\
\text { Welfare } \\
\end{array}$ & & & & & & $\mathrm{Y}$ & & & & & & $\mathrm{Y}$ & & $\mathrm{Y}$ & $\mathrm{Y}$ & & \\
\hline $\mathrm{X}$ & $\begin{array}{c}\text { Infrastructure } \\
\text { Support }\end{array}$ & & & $\mathrm{Y}$ & $\mathrm{Y}$ & & $\mathrm{Y}$ & $\mathrm{Y}$ & $\mathrm{Y}$ & $\mathrm{Y}$ & & $\mathrm{Y}$ & $\mathrm{Y}$ & $\mathrm{Y}$ & & & & \\
\hline XI & $\begin{array}{l}\text { Inequality } \\
\text { Reduction } \\
\end{array}$ & $\mathrm{Y}$ & $\mathrm{Y}$ & $\mathrm{Y}$ & $\mathrm{Y}$ & & & & & & & $\mathrm{Y}$ & & & & & $\mathrm{Y}$ & \\
\hline XII & $\begin{array}{c}\text { Social } \\
\text { Development }\end{array}$ & & & & $\mathrm{Y}$ & $\mathrm{Y}$ & & & $\mathrm{Y}$ & $\mathrm{Y}$ & & $\mathrm{Y}$ & $\mathrm{Y}$ & $\mathrm{Y}$ & $\mathrm{Y}$ & $\mathrm{Y}$ & $\mathrm{Y}$ & \\
\hline XIII & $\begin{array}{c}\text { Livelihood } \\
\text { Enhancement }\end{array}$ & $\mathrm{Y}$ & $\mathrm{Y}$ & & & & & & & & & $\mathrm{Y}$ & & & & & & \\
\hline XIV & $\begin{array}{l}\text { Capacity } \\
\text { Building } \\
\end{array}$ & & & & & & & $\mathrm{Y}$ & $\mathrm{Y}$ & $\mathrm{Y}$ & & & $\mathrm{Y}$ & & & & & \\
\hline $\mathrm{XV}$ & $\begin{array}{c}\text { Promotion of } \\
\text { Art and } \\
\text { Culture } \\
\end{array}$ & & & & & & & & & & & $\mathrm{Y}$ & & & & & & \\
\hline XVI & $\begin{array}{c}\text { Disaster } \\
\text { Management }\end{array}$ & & & & & & & & & & & $\mathrm{Y}$ & $\mathrm{Y}$ & & & & & \\
\hline XVII & $\begin{array}{c}\text { Women } \\
\text { Empowerment }\end{array}$ & $\mathrm{Y}$ & & $\mathrm{Y}$ & $\mathrm{Y}$ & $\mathrm{Y}$ & & & $\mathrm{Y}$ & & & $\mathrm{Y}$ & & & & & & \\
\hline
\end{tabular}

(VT = Vocational Training, SD = Skill Development, **: Includes reduction in Hunger and Malnutrition) 


\section{Inferences}

1. As the Companies prefer to Education and Health Care, out of 17 goals, only 6 goals are directed by the CSR activities.

2. Other CSR activities are in direction of general upliftment of the Poor and Unprivileged sections of the society, but do not have any connection with addressing gender and such inequalities.

3. The Companies spend on separately for making the technology safe, mitigating the risk etc. which are included in a separate report giving detail about Conservation of Energy. The authors have not taken it into consideration because they had not intended to do so which is clear from the objective part of the paper.

4. However, this point is mentioned here because the activities under that domain also have direction towards the achievement of SDGs. Those efforts are also much roundabout and not so specific with explicit connection to any SDG.

\section{RECOMMENDATIONS}

\section{Linkage to Turnover}

Table No 07: CSR spending linked to Turnover and differed liability Rs in Crores

\begin{tabular}{|l|r|r|r|r|r|r|}
\hline Accounting Year & Turnover & $\begin{array}{c}1 \% \\
\text { Turnover }\end{array}$ & of & $\begin{array}{c}\text { Expected } \\
\text { CSR Spending }\end{array}$ & $\begin{array}{c}\text { Actual } \\
\text { Spent }\end{array}$ & Balance \\
\hline $2018-19$ & 200.00 & 2.00 & 2.00 & 1.50 & 0.50 & 0.50 \\
\hline $2019-20$ & 250.00 & & 2.50 & 2.50 & 2.75 & 0.25 \\
\hline
\end{tabular}

The suggestion is made with reference to the following grounds

i. The companies form the trust and handover the funds to the trust.

ii. The Trust embarks on long term projects and they run for quiet longer period than expected.

iii. They remain incomplete because of shortage of funds which entirely depends on the profits of the company.

iv. Such work in progress stage for a long period takes out the essence of the benefit for the beneficiaries.

v. As suggested, when it is linked to turnover and committed as the obligation, in some way, the funds shall be assured to the project which would help the company to discharge their responsibility in more effective and efficient manner.

However, this suggestion of linking the turnover may induce the companies to come heavily on government. Thus, the authors are aware of this fact and further suggest that, there should be certain deliberations on $\%$ to Turnover and other related issues between the ministry of Company Affairs, Company Law Board and Federation of Indian Chamber of Commerce and Industries and other Associations.

In nutshell, the suggestion is with the spirit of commitment of funds for the rapid completion of the projects, in the best interest of the beneficiaries because CSR is not a static one but having its perpetuality until the
From the table 03, it is seen that CSR spending is not even $1 \%$ of turnover. It is suggested that it should be linked to turnover instead of profits. The Government may limit the volume of expenditure on CSR activities in differed manner.

\section{Illustration:}

XYZ Ltd has the turnover of Rs. 200 Crores, during the accounting year 2018-19. Then it should spend 1\% i.e. Rs. 2.00 Crores if linked to turnover. In case, due to insufficient profits, if the company is in a position to spend only Rs. 1.5 Crores, then there should be a balance Rs. of 0.50 Crores kept unspent as liability to be discharged in the next year. This balance is to be bridged up in the future years when the profits would be enough.

Suppose for the next year, the turnover of the company is Rs. 250 Crores, then they need to spend

Rs. 2.5 Crores of that year as well as Rs.0.50 Crores of the last year. In this year it spends Rs. 2.75 Crores, then the balance would be of Rs. 0.25 Crores. The company should set off, spending on CSR against such balance first and carry forward the balance which is to be covered along with the next year's amount arrived at $1 \%$ of the next year's turnover. The example is shown in the following table. company is in existence. Finally, it should come after evolving the right consensus.

\section{Evaluation by Investors}

From table 04 it is seen that from the sample 50\% Companies have spent less than budgeted volume. It is suggested that while evaluating the company, the investors should also look at the CSR Report with more gravity as it reveals the ethical stance of the company.

\section{Preference to Public Health Research}

It is suggested that these companies should spend on Public Health Research and Education much more as it would enhance the sustainable benefits and growth of the society.

\section{CSR Activities and SDGs}

\section{a) Reference to SDGs in CSR report}

The company should refer to the direction towards these goals which would make their information more meaningful.

\section{b) Selection of sector and SDGs}

While, selecting the sector of activities, the company can choose the sector which is not covered by other companies and can work for the same.

\section{c) Exclusive approach}

The Company can develop a strategy to work on single area or sector where they can focus and derive the benefits of concentrated efforts and specialization.

\section{d) Consortium Approach}

Instead of working alone, the companies can have a strategy of alliance (which they do for 
Marketing and Technology), which would enable them to take bigger projects. Similarly, they can create synergic effect to the complete the projects before the deadlines.

This would result in enlarging the number of beneficiaries as well the different sections of the society.

\section{e) Role of Chambers and Associations}

In order to facilitate the alliance, Chambers and Associations can play a cartelistic role to generate a common platform which can be considered as CSR activity of such organizations.

In brief, if the suggestions are implemented with suitable alterations and modifications, then the companies would conduct the activities in more effective manner and in most pragmatic way

\section{f) Details of activities.}

The companies have mentioned main sector but they have not given any details of activities. The examples of such sector are Animal Welfare, Women Empowerment, Disaster Management, Livelihood Enhancement, Inequality

It is suggested for clear comprehension of different stakeholders, the company should describe in detail the nature of activities against each sector to the best extent.

\section{g) Legal to legacy approach}

The government has prescribed the activities to be considered for CSR which are given under schedule VII to Companies Act 2013. From the matter given in the schedule it is noted that there is no reference to UNDP Sustainability Development Goals.

It is suggested both the government as well as the companies should take CSR activities not purely as legal compliance but moreover in the true spirit of legacy.

\section{Health care and blood banks}

From the list of activities under sector II given before do not include any spending on Blood Bank Activities. Considering the demand for the blood, the company should consider them with higher priority.

\section{CONCLUSION}

Although mandatory, the companies are spending through the vehicle of CSR, which is worth of appreciation, need to build strategy of CSR (with reference to SDGs) and they should be more integrated approach and ways. This shall result into enlarging the benefits of poor and unprivileged sections of the society. The authors have attempted to look at CSR Strategy and building Philosophy

The same should be well spelt out the beginning of the report, to clear understanding of all the stakeholders.

\section{LIMITATIONS}

1 The number of companies can be increased which are limited to 10. However the paper is of conceptual nature and the number has not affected the scope of perspective view.

2 The data taken is only for one accounting year i.e. 2018-19 Reduction etc.

\section{FURTHER SCOPE OF RESEARCH}

1. The study can be conducted for other sectors, particularly service sectors

2. It can pertain to a block of 5 years and analysis can be made with more quantitative aspects regarding spending for CSR.

3. Comparative study can be conducted for different sectors like Manufacturing against Service Sector.

4. Post evaluation study for impact can be conducted for each sector domain according to spending of the company.

\section{REFERENCES:}

1. Voluntary National Review Report - India (2017), Report to be presented to The High-Level Political Forum on Sustainable Development, New York/July 2017

(Source: https://www.in.undp.org/content/india/en/home/about-us.html)

2. UNDP Sustainable Development Goals

(Source

https://www.undp.org/content/dam/undp/library/corporate/brochure/SD Gs_Booklet_Web_En.pdf.)

3. AmbarishVerma (2019) - Top 15 Pharma Companies in India.

(Source:https://www.marketresearchreports.com/blog/2019/04/11/top-1 5-pharma-companies-India)

4. Elena Giovannoni and GiacomoFabietti (2014): What is Sustainability? A Review of The Concept and Its Application

5. Annual report of 10 Pharma companies In India, for the year ended as on $31^{\text {st }}$ Mar 2019

6. Definition of CSR given by World Business Council for Sustainable Development,

WBCSD

(http://www.gaea.bg/about-GAEA/corporate-social-responsibility.html)

7. Definition of Sustainable Development: (The Brundtland Commission report released in 1987 by United Nations World Commission on Environment and Development)

(Source

:https://www.slideshare.net/pamelalibrarian/sustainable-development-po werpoint?next slideshow=2)

8. Definition of Sustainable Consumption

(Source: https://sustainabledevelopment.un.org/index.php?menu=204)

9. HawkenP,Lovins LH(1999) Natural capitalism:creating the next industrial revolution. Little, Brown, Bostan MA

10. Davis K (1960) Can business afford to ignore social responsibilities? CalifManag Rev 2;70-76

\section{AUTHORS PROFILE}

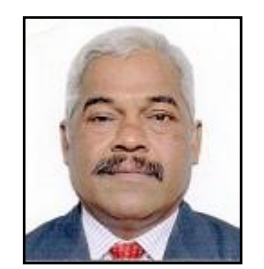

CMA. (Dr) Damodar R Kulkarni, B.Com LL.B, FCMA, Ph.D. Association with Industry

Total experience of 35 years in various industries. I have varied experience in various functions of Finance like Product Costing, Financial Accounting, Inventory Management, Budgetary Control, MIS, Statutory Audit, Cost Audit, Excise, Customs, Foreign Exchange, Stores, and Purchase etc.Finance professional. Fellow member of "Institute of Cost Accountants of India"Doctor of Philosophy (Ph.D.) Savitribai Phule Pune University has awarded in Aug 2019 for research work.

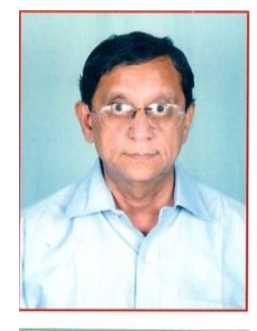

1. Name: Dr. Ashok GRanade

2. Educational Qualification : M.Com. MMS.,MA.(Eco)., GDCA., Ph.D (Pune University)

3. Association with Industry

I. Associated with SMEs in Finance function for 20 Years.

II. Supported and guided SMEs in starting the unit and setting up Finance System.

4. Association with Academic Institutions

More than 25 years association with various institutes in the fileds of teaching and administration. Following are the important contributions. 